OPEN ACCESS

Check for updates

\title{
Hospital admission and mortality rates for non-covid diseases in Denmark during covid-19 pandemic: nationwide population based cohort study
}

\author{
Jacob Bodilsen, ${ }^{1}$ Peter Brønnum Nielsen,, ${ }^{2,3}$ Mette Søgaard, ${ }^{2,3}$ Michael Dalager-Pedersen, ${ }^{1}$ \\ Lasse Ole Zacho Speiser, ${ }^{4}$ Troels Yndigegn, ${ }^{5}$ Henrik Nielsen, ${ }^{1,6}$ Torben Bjerregaard Larsen, ${ }^{2,3}$ \\ Flemming Skjøth ${ }^{2,7}$
}

${ }^{1}$ Department of Infectious

Diseases, Aalborg University

Hospital, Aalborg, Denmark

${ }^{2}$ Aalborg Thrombosis Research

Unit, Aalborg University, Aalborg,

Denmark

${ }^{3}$ Department of Cardiology,

Aalborg University Hospital,

Aalborg, Denmark

${ }^{4}$ Department of Radiology, Aarhus University Hospital,

Aarhus, Denmark

${ }^{5}$ Department of Cardiology, Lund University Hospital, Lund, Sweden

${ }^{6}$ Department of Clinical Medicine, Aalborg University,

Aalborg, Denmark

${ }^{7}$ Unit of Clinical Biostatistics, Aalborg University Hospital, Aalborg, Denmark

Correspondence to: J Bodilsen jacob.bodilsen@rn.dk

(ORCID 0000-0002-7398-814X) Additional material is published online only. To view please visit the journal online.

Cite this as: $B M J$ 2021;373:n1135 http://dx.doi.org/10.1136/bmj.n1135

Accepted: 26 April 2021

\section{ABSTRACT}

OBJECTIVE

To determine the incidence of hospital admissions and associated mortality rates for non-covid medical conditions during the covid-19 pandemic.

DESIGN

Nationwide, population based cohort study.

SETTING

Denmark from 13 March 2019 to 27 January 2021.

PARTICIPANTS

All Danish residents $>1$ year of age.

MAIN OUTCOMES MEASURES

Population based healthcare registries that encompass the entire Danish population were used to compare hospital admission and mortality rates during the covid-19 pandemic (from 11 March 2020 to 27 January 2021) with the prepandemic baseline data (from 13 March 2019 to 10 March 2020). Hospital admissions were categorised as covid-19 when patients were assigned a diagnosis code for covid-19 within five days of admission. All patients were followed until migration, death, or end of followup, whichever came first. Rate ratios for hospital admissions were computed using Poisson regression and were directly standardised using the Danish population on 1 January 2019 as reference. 30 day mortality rate ratios were examined by Cox regression, adjusted for age and sex, and covid-19 diagnosis was used as a competing risk.

RESULTS

5753179 residents were identified during 567.8 million person weeks of observation, with 1113705

\section{WHAT IS ALREADY KNOWN ON THIS TOPIC}

Early observations during the covid-19 pandemic suggest that patients might not have sought help for cardiovascular or neurological diseases

Some hospitals, overwhelmed by the pandemic, might not have been able to provide timely care for other serious and acute non-covid-19 medical conditions

\section{WHAT THIS STUDY ADDS}

Hospital admissions for all major non-infectious disease groups decreased during the two national lockdowns in Denmark

A gradual return to baseline levels was observed between lockdowns except for respiratory and nervous system diseases, cancer, heart failure, sepsis, and pneumonia

Higher 30 day mortality rates were observed for most major disease groups during national lockdowns, but also between lockdowns for hospital admissions due to respiratory diseases, cancer, pneumonia, and sepsis hospital admissions among 675447 people. Compared with the prepandemic baseline period (mean hospital admission rate 204.1 per $100000 /$ week), the overall hospital admission rate for noncovid-19 conditions decreased to 142.8 per $100000 /$ week (rate ratio $0.70,95 \%$ confidence interval 0.66 to 0.74 ) after the first national lockdown, followed by a gradual return to baseline levels until the second national lockdown when it decreased to 158.3 per $100000 /$ week $(0.78,0.73$ to 0.82$)$. This pattern was mirrored for most major diagnosis groups except for non-covid-19 respiratory diseases, nervous system diseases, cancer, heart failure, sepsis, and noncovid-19 respiratory infections, which remained lower throughout the study period. Overall 30 day mortality rates were higher during the first national lockdown (mortality rate ratio $1.28,95 \%$ confidence interval 1.23 to 1.32 ) and the second national lockdown $(1.20,1.16$ to 1.24$)$, and these results were similar across most major diagnosis groups. For non-covid-19 respiratory diseases, cancer, pneumonia, and sepsis, the 30 day mortality rate ratios were also higher between lockdown periods.

\section{CONCLUSIONS}

Hospital admissions for all major non-covid-19 disease groups decreased during national lockdowns compared with the prepandemic baseline period. Additionally, mortality rates were higher overall and for patients admitted to hospital with conditions such as respiratory diseases, cancer, pneumonia, and sepsis. Increased attention towards management of serious non-covid-19 medical conditions is warranted.

\section{Introduction}

The covid-19 pandemic has caused a global health crisis of historic proportions and has forced governments worldwide to impose dramatic restrictions within and between countries. These restrictions include hygienic precautions and measures of physical distancing such as quarantines, restrictions on public and private gatherings, and closure of schools, public workplaces, private businesses, and country borders. ${ }^{1}$

Government officials and hospital administrators have also prioritised healthcare services to decrease risks of system collapse. However, these prioritisations and public information campaigns of self-isolation could endanger patients with serious and acute non-covid-19 medical conditions. ${ }^{2}$ Previous studies examining hospital admission rates during the pandemic have mainly focused on a single noncovid-19 acute medical condition, and most have 
been restricted to one or a few hospitals within a certain healthcare programme or geographical region during a relative short period of time. ${ }^{3-13}$ Analyses of essential healthcare services at times of crisis are crucial for managing hospital responses and ensuring preparedness during the continued threat of covid-19 and future epidemics. This study examined changes in hospital admission and mortality rates during the first 11 months of the covid-19 pandemic in Denmark using nationwide and population based healthcare registries.

\section{Methods}

Setting and study population

This nationwide cohort study included data from 13 March 2019 to 27 January 2021 and covered the entire Danish population (5827 463 residents on 1 January 2019; supplementary fig 1). In Denmark, the state provides all residents with free and unrestricted access to healthcare. ${ }^{14} \mathrm{~A}$ unique civil registration number is assigned to each resident at birth or immigration and is used for all healthcare contacts in Denmark. Data are recorded prospectively in nationwide registries, allowing longitudinal surveillance of the entire population at the individual level.

\section{Data sources and study period}

The Civil Registration System tracks migration, sex, age, and vital status of all Danish residents, with less than 0.3\% lost to follow-up. ${ }^{15}$ The Danish National Patient Registry covers all somatic hospitals in Denmark and has recorded discharge diagnoses of acute and elective hospital admissions since 1977, and outpatient clinic visits since $1995 .^{16}$ Since 1994 , diagnoses have been coded according to the World Health Organization's international classification of diseases version 10 (ICD-10). A major change in registration practices in the Danish National Patient Registry was implemented during January and February 2019 and therefore the study period started in March 2019 to ensure the internal validity of records for hospital admissions. Hospital admissions less than 12 hours apart were considered as one continued contact. Inpatient hospital admissions were defined as hospital contacts crossing midnight and of at least 12 hours' duration. Data were excluded for infants ( $<1$ year of age) and for people with recent migration status or inconsistent vital data (supplementary fig 2).

\section{Pandemic stages and preventive measures}

On 27 February 2020, the first Danish patient with covid-19 was identified after returning home from northern Italy. Within weeks, covid-19 became widely transmitted in the Danish community (fig 1). On 11 March 2020 the Danish government issued a comprehensive lockdown in Denmark, with the closure of schools and most workplaces, and the implementation of quarantines, border closings, and restriction on public gatherings. ${ }^{17}$ Some hospitals suspended non-urgent elective surgery and outpatient visits in preparation for an expected high number of covid-19 admissions; on 17 March, this suspension was extended to all Danish hospitals. The number of new patients with covid-19 quickly decreased after the national lockdown, and from 15 April onwards restrictions were gradually rolled back. During summer 2020, covid-19 incidence remained low and hospitals reduced the backlog of patients requiring non-urgent care. However, by the autumn, several regional outbreaks had occurred, which led to a second and more severe wave of covid-19 on a national level in late 2020. Therefore, in Denmark six phases of the covid-19 pandemic can be defined:

1. Pre-covid-19 baseline from 13 March 2019 to 10 March 2020

2. First national lockdown phase from 11 March to 15 April 2020

3. Gradual reopening phase from 16 April to 8 June 2020

4. Few restrictions from 9 June to 30 September 2020

5. Regional lockdown phase from 1 October to 15 December 2020

6. Second national lockdown from 16 December 2020 to 27 January 2021.

\section{Outcomes}

From 13 March 2019 to 27 January 2021, all noncovid-19 hospital admissions were identified by principal diagnosis codes in the Danish National Patient Registry. These codes were grouped according to major ICD-10 diagnosis group (supplementary table 1) identified by the first primary code given within the listed chapters. However, if a patient was assigned a diagnosis code for covid-19 within five days of hospital admission, the admission was categorised as covid-19. We used the Civil Registration System to compute 30 day mortality rates for non-covid-19 hospital admissions, overall and according to selected major disease groups. Because covid-19 could have been associated with changes in essential medical services in Denmark, all analyses were repeated for selected acute medical conditions diagnosed within 24 hours of hospital admission: myocardial infarction, heart failure, stroke, intracranial bleeding, exacerbation of chronic pulmonary disease, pneumonia, sepsis, urinary tract infection, and bone, skin and soft tissue infections.

\section{Statistical analyses}

We examined overall hospital admission rates stratified by major disease groups. For these analyses, direct standardisation was performed by using the age (10 year intervals) and sex distribution of the Danish population on 1 January 2019 as reference. We used a Poisson regression model, with log of the population size as offset, to estimate standardised weekly hospital admission rates. The rates were adjusted for number of working days per week and public holidays because elective hospital contacts are mainly scheduled during regular weekdays. We computed hospital admission 


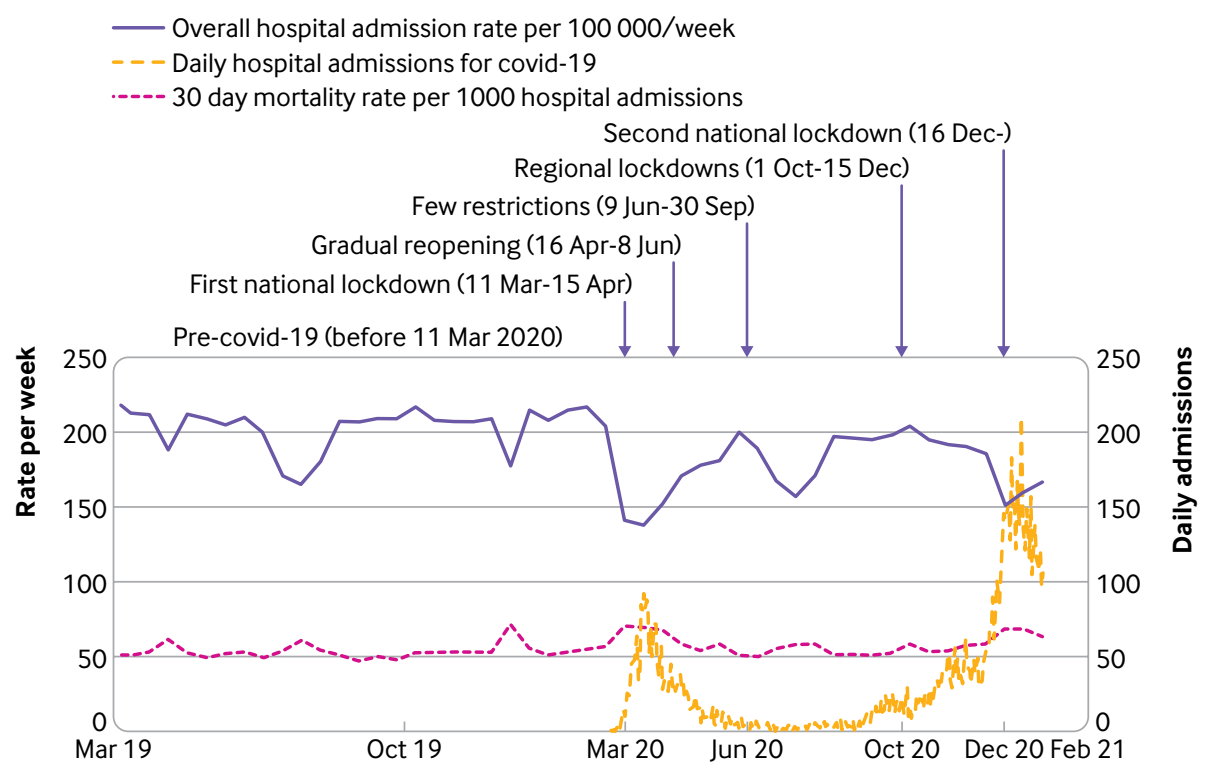

Fig 1 | Standardised overall hospital admission rates, absolute number of daily admissions for covid-19, and 30 day mortality rates in Denmark during covid-19 pandemic

rate ratios and $95 \%$ confidence intervals by using the pre-covid-19 baseline period as reference. A sandwich estimator for robust estimation of covariances was used to account for potential overdispersion. We then repeated the analyses for biweekly periods and stratified patients as having prevalent disease, when the patient had previously been assigned a hospital diagnosis code for the major disease group or medical condition, or incident disease, when a hospital diagnosis code was first assigned for the major disease group or medical condition.

We assessed mortality risk at 30 days after noncovid-19 hospital admission by using the Kaplan-Meier estimator, with censoring at emigration, diagnosis of covid-19, or end of follow-up (28 February 2021), whichever occurred first. Mortality risk ratios and robust $95 \%$ confidence intervals were calculated using Cox proportional regression models adjusted for age and sex, and using a diagnosis of covid-19 within 30 days after the index date as competing risk. Because we excluded people with inconsistent vital status, there were no missing data for hospital admissions or death.

We used Stata MP version 16 (Statacorp, College Station, TX) for all statistical analyses, and a $\mathrm{P}$ value of 0.05 was applied for testing statistical significance.

\section{Patient and public involvement}

Patients were not included in the design or conduct of this study. Barriers for including patient and public involvement were time sensitivity in carrying out the study (covid pandemic) and lack of funding.

\section{Results}

The study comprised 5753179 Danish residents identified during 567.8 million person weeks of observation, yielding a total of 1113705 hospital admissions distributed among 675447 people (table
1). Of those admitted to hospital, $68.5 \%$ were admitted once, $17.5 \%$ were admitted twice, and $14 \%$ had three or more admissions during the study period.

The overall mean hospital admission rate in Denmark was 204.1 per 100000/week during the baseline period (table 2), and approximately 210 when not considering periods of decreased activity such as Christmas, Easter, and summer holidays (fig 1). When we used the baseline period as reference, the mean hospital admission rate for non-covid-19 conditions decreased to 142.8 (rate ratio $0.70,95 \%$ confidence interval 0.66 to 0.74 ) after the first national lockdown, 178.6 (0.88, 0.84 to 0.92$)$ during the gradual reopening phase, $188.8(0.92,0.90$ to 0.96$)$ during the period with few restrictions, 193.9 (0.95, 0.92 to 0.98$)$ during the regional lockdown phase, and 158.3 (0.78, 0.73 to 0.82 ) during the second national lockdown.

\section{Hospital admission rates for major disease groups} Compared with hospital admissions for infectious disease during the prepandemic baseline period, the hospital admission rate ratio for non-covid-19 infectious diseases was 0.73 (95\% confidence interval 0.70 to 0.76 ) during the first national lockdown (table 2). Lower hospital admission rates followed, with rate ratios of 0.85 ( 0.81 to 0.89$)$ during the gradual reopening phase, 0.93 (0.90 to 0.97$)$ during the period with few restrictions, 0.90 (0.88 to 0.92) during regional lockdowns, and 0.77 (0.75 to 0.80$)$ during the second national lockdown.

For all other major diagnosis groups, hospital admission rate ratios decreased markedly during the first and second national lockdowns compared with the rates during the baseline period, ranging from 0.34 (0.25 to 0.46 ) for bone, muscle, and connective tissue diseases to 0.86 (0.80 to 0.91$)$ for cancer during the first national lockdown. These lower rates were mainly driven by fewer hospital admissions 


\begin{tabular}{|c|c|c|c|c|c|c|c|}
\hline \multirow[b]{2}{*}{ Characteristics } & \multirow[b]{2}{*}{ Overall population } & \multicolumn{6}{|c|}{ Hospital admissions } \\
\hline & & Baseline & $\begin{array}{l}\text { First national } \\
\text { lockdown }\end{array}$ & $\begin{array}{l}\text { Gradual } \\
\text { reopening }\end{array}$ & Few restrictions & $\begin{array}{l}\text { Regional } \\
\text { lockdowns }\end{array}$ & $\begin{array}{l}\text { Second national } \\
\text { lockdown }\end{array}$ \\
\hline No of people & 5753179 & 416034 & 46362 & 64433 & 151824 & 98410 & 58706 \\
\hline Age (years), mean (SD) & $41.8(23.4)^{\star}$ & $59.9(22.4)$ & $61.0(22.0)$ & $60.5(22.2)$ & $60.2(22.4)$ & $60.6(22.1)$ & $61.8(21.9)$ \\
\hline $0-20$ & $21.4(1231783)^{\star}$ & $5.7(35152)$ & $4.6(2375)$ & $5.2(3852)$ & $5.4(10281)$ & $5.3(6091)$ & $4.4(2931)$ \\
\hline $21-40$ & $25.4(1463171)^{\star}$ & $15.8(97329)$ & $15.9(8290)$ & $15.6(11472)$ & $16.2(30851)$ & $15.4(17805)$ & $15.3(10183)$ \\
\hline $41-60$ & $27.0(1553768)^{\star}$ & $18.8(115783)$ & $17.9(9300)$ & $18.4(13476)$ & $18.2(34704)$ & $18.4(21296)$ & $17.5(11683)$ \\
\hline $61-80$ & $21.4(1230024)^{*}$ & $40.3(248065)$ & $41.0(21325)$ & $40.5(29732)$ & $40.2(76564)$ & $40.9(47390)$ & $40.4(26950)$ \\
\hline$\geq 81$ & $4.8(274433)^{\star}$ & $19.3(118877)$ & $20.7(10755)$ & $20.3(14885)$ & $20.0(38077)$ & $20.1(23269)$ & $22.4(14962)$ \\
\hline Female population & $50.3(2892854)^{\star}$ & $53.6(329970)$ & $52.6(27361)$ & $53.3(39141)$ & $53.8(102384)$ & $53.6(62086)$ & $53.0(35327)$ \\
\hline No of hospital admissions & 1113705 & 615206 & 52045 & 73417 & 19477 & 115851 & 66709 \\
\hline $\begin{array}{l}\text { Million person weeks } \\
\text { of observation }\end{array}$ & 567.8 & 299.2 & 29.6 & 44.4 & 94.0 & 62.7 & 38.0 \\
\hline
\end{tabular}

$\mathrm{SD}=$ standard deviation.

Overall population from 13 March 2019 to 27 January 2021; baseline period from 13 March 2019 to 10 March 2020 , 364 days; first national lockdown from 11 March 2020 to 15 April 2020 ,

36 days; gradual reopening from 16 April 2020 to 8 June 2020, 54 days; few restrictions from 9 June 2020 to 30 September 2020,114 days; regional lockdowns from 1 October 2020 to 15

December 2020, 76 days; second national lockdown from 16 December 2020 to 27 January 2021, 46 days.

*Population characteristics in Denmark on 11 March 2020.

among patients with previously diagnosed conditions (prevalent disease) in most specialties, including those with extensive outpatient appointments or elective admissions (fig 2). However, substantially lower rates were also observed among first time hospital admissions (incident disease) for conditions such as respiratory, circulatory, neurological, haematological, digestive, and psychiatric diseases during the first national lockdown.

Compared with the prepandemic baseline period, hospital admission rates remained consistently lower for several major disease groups during the phases of gradual reopening, few restrictions, and regional lockdowns, including respiratory diseases, cancer, and nervous system diseases. For respiratory diseases, the rate ratios were 0.63 ( 0.60 to 0.66 ) during gradual reopening, 0.73 ( 0.70 to 0.77$)$ during few restrictions, and 0.70 (0.66 to 0.73 ) during regional lockdowns. Although generally less severe in magnitude, the lower hospital admission rates observed during the second national lockdown for all major disease groups mirrored those of the first national lockdown.

\section{Hospital admission rates for selected acute medical} conditions

Compared with the baseline period, hospital admissions were significantly lower for all non-covid-19 infections during the first and second national lockdowns. The hospital admission rate ratios were 0.64 (95\% confidence interval 0.58 to 0.69 ) for bone, skin, and soft tissue infections, 0.65 (0.61 to 0.69) for acute exacerbation of chronic pulmonary disease, 0.71 ( 0.60 to 0.83 ) for pneumonia, 0.76 (0.68 to 0.85 ) for urinary tract infections, and 0.77 (0.73 to 0.82$)$ for sepsis during the first national lockdown. The observed lower rates were comparable among patients with prevalent and incident disease (fig 3). Hospital admission rates for all non-covid-19 infections remained lower throughout the study period except for urinary tract infections and bone, skin, and soft tissue infections, which returned to baseline levels by the gradual reopening and few restrictions periods, respectively.

Substantially fewer hospital admissions for some non-infectious acute medical conditions were also observed during the first national lockdown compared with the prepandemic baseline period, with rate ratios of 0.74 (0.65 to 0.83 ) for heart failure, 0.89 (0.79 to 0.99 ) for intracranial bleeding, 0.89 (0.86 to 0.93) for stroke, and 0.90 ( 0.80 to 1.01$)$ for myocardial infarction. The observations were predominated by fewer first time hospital admissions for myocardial infarction and stroke, whereas the lower rates for heart failure were attributable to a combination of fewer hospital admissions among patients with prevalent and incident disease. Hospital admission rates remained lower for heart failure throughout the study period and returned to baseline levels for myocardial infarction, stroke, and intracranial bleeding later during the study period, including the second national lockdown.

\section{Mortality}

Major disease groups-the overall 30 day mortality rate ratios among people admitted to hospital increased during the first national lockdown (1.28, 95\% confidence interval 1.23 to 1.32 ) and the second national lockdown $(1.20,1.16$ to 1.24$)$ compared with the prepandemic baseline period (table 3 ). The same pattern was observed for a range of major disease groups and acute medical conditions, such as noncovid-19 infections, bone, muscle, and connective tissue, genitourinary, respiratory, digestive, and circulatory diseases, and injuries or poisoning. However, the 30 day mortality rate ratios also remained higher for infectious diseases overall (with and without covid-19), cancer, and respiratory diseases in time periods between the two national lockdowns.

Acute medical conditions-compared with the prepandemic baseline period, the 30 day mortality rate ratio was 1.40 (95\% confidence interval 1.27 to 1.55) for pneumonia, 1.39 (1.23 to 1.57) for sepsis, 


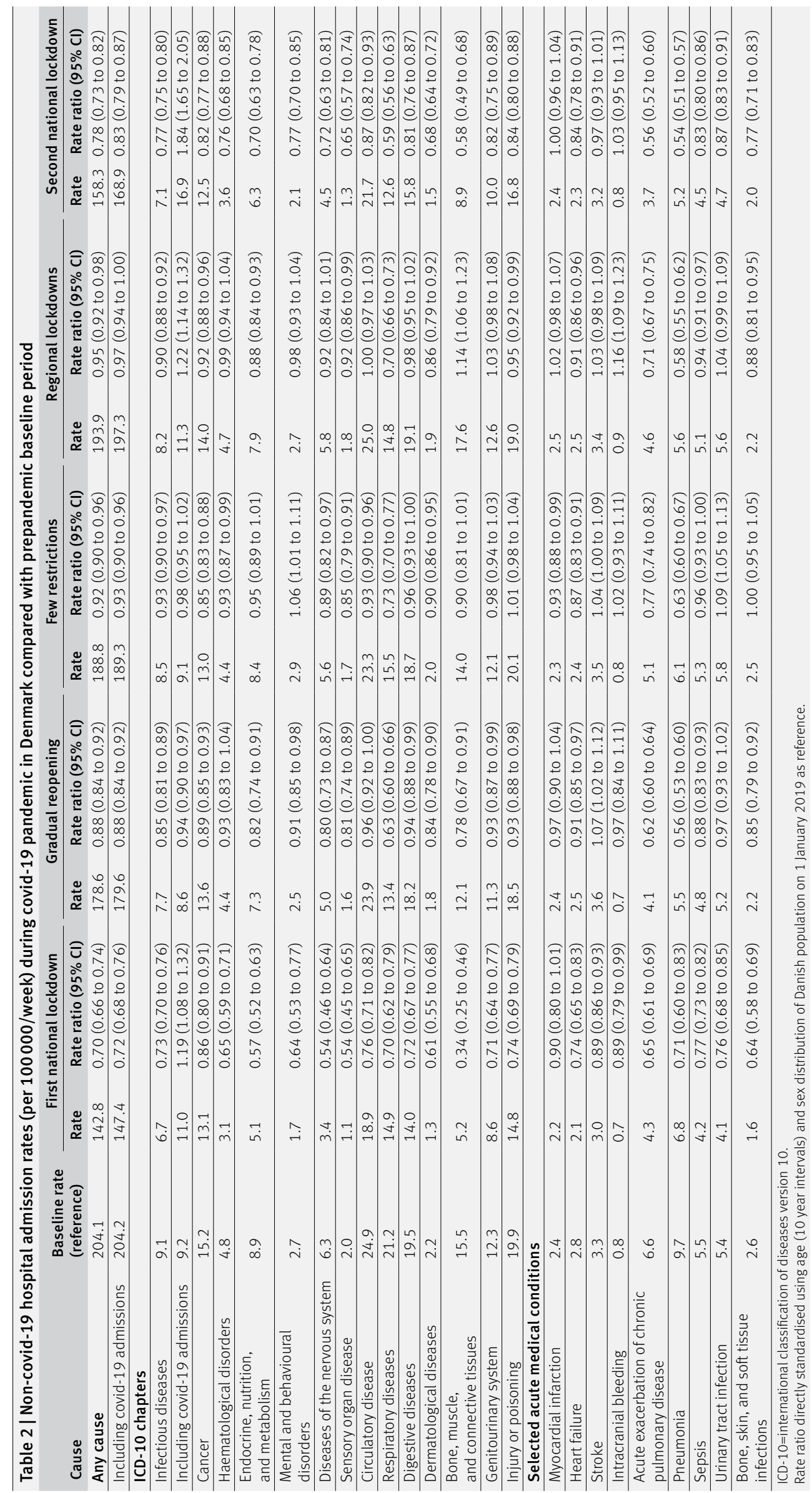



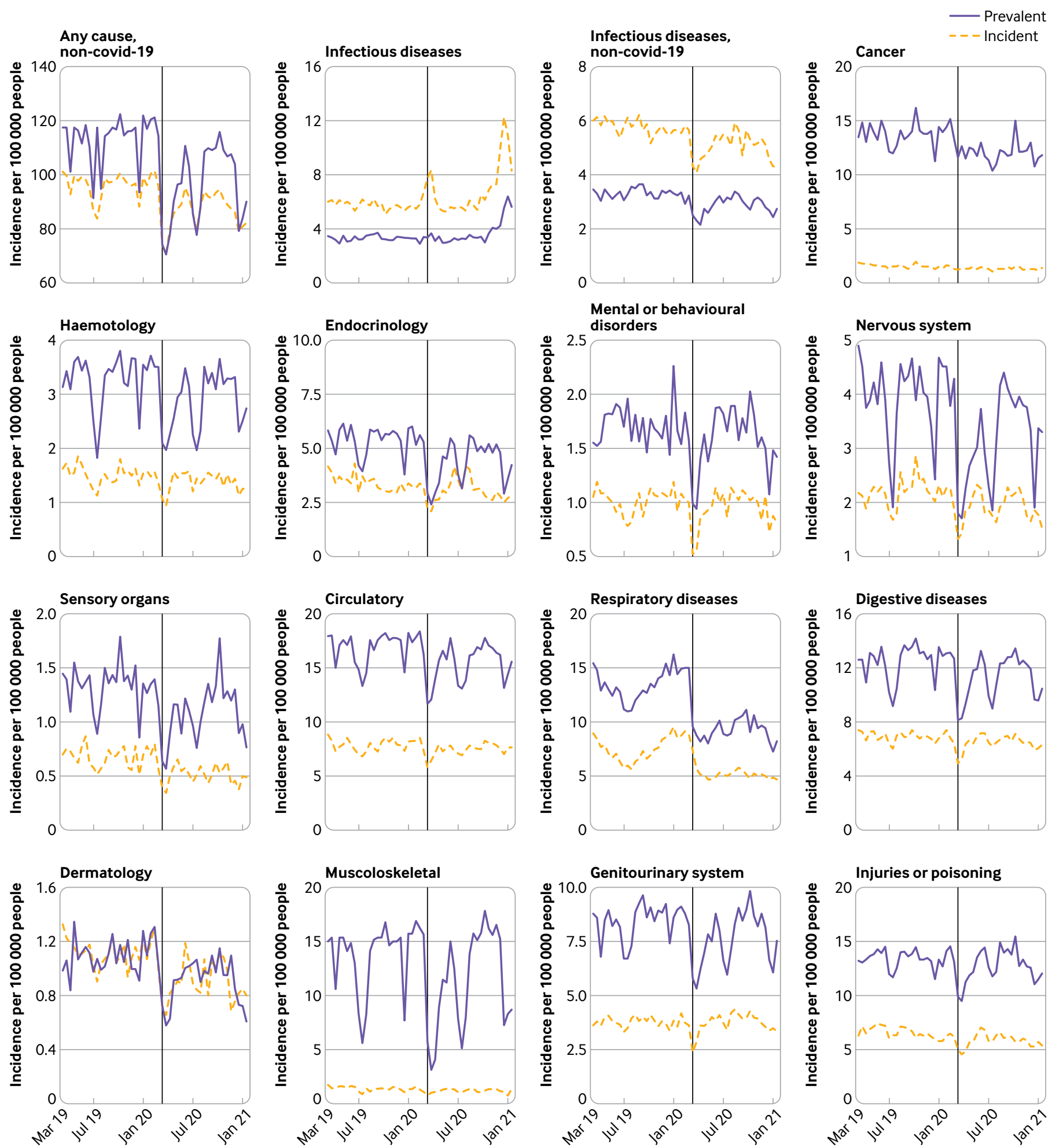

Fig 2 | Non-covid-19 hospital admission rates by ICD-10 (international classification of diseases version 10) chapters in Denmark from March 2019 to January 2021. Data are stratified according to whether hospital admission concerns patients with prevalent or incident disease

and 1.23 (1.01 to 1.50) for urinary tract infections during the first national lockdown. For patients with a diagnosis of sepsis, the 30 day mortality rates were also higher during regional lockdowns, whereas rates remained raised for pneumonia throughout the study period.

\section{Discussion}

Principal findings

We used nationwide, population based healthcare registries encompassing the entire Danish population and observed 30\% and 22\% lower overall hospital admission rates during the two national lockdowns 

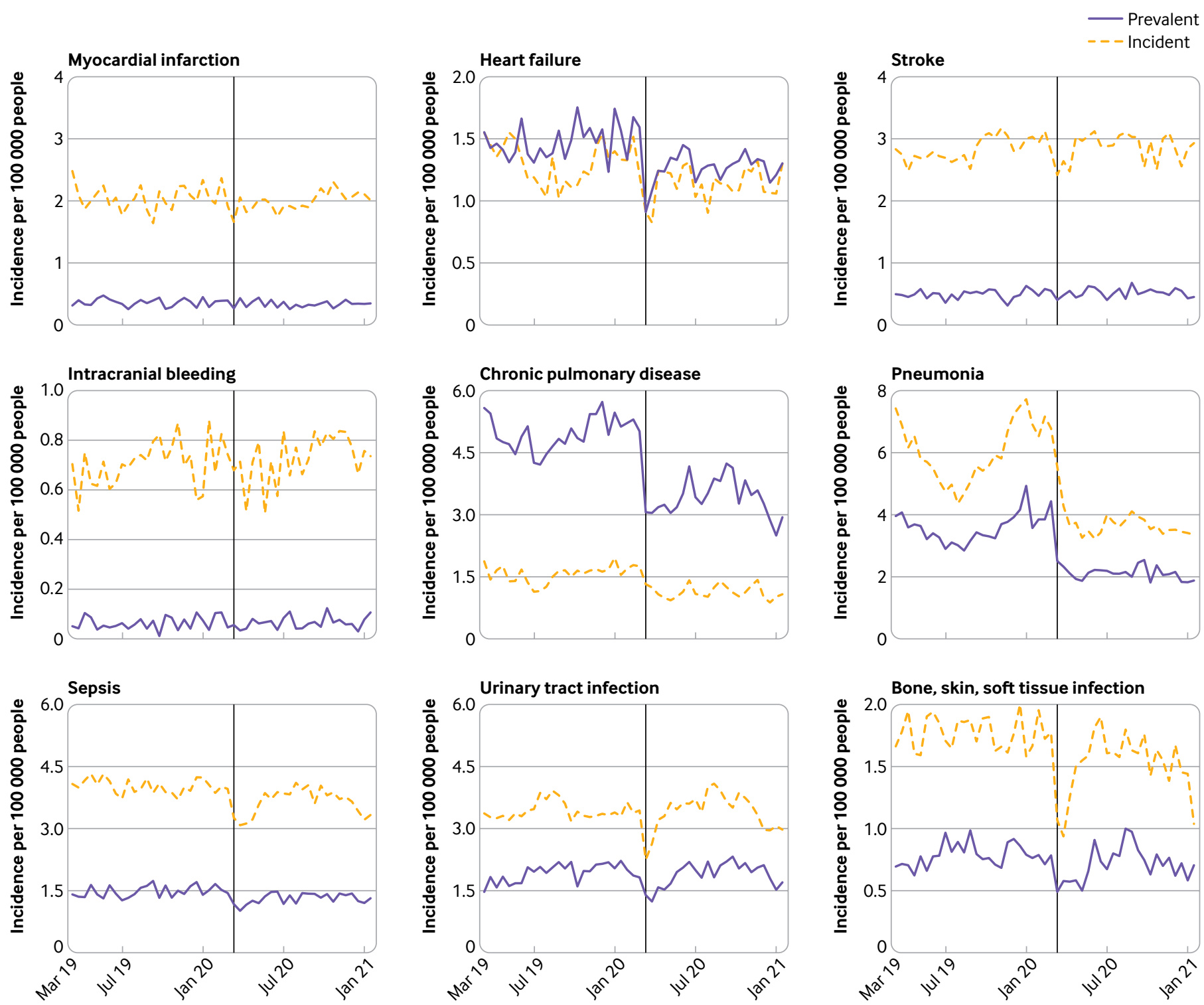

Fig 3 | Hospital admission rates by selected acute medical conditions in Denmark from March 2019 to January 2021. Data are stratified according to whether hospital admission concerns patients with prevalent or incident disease

in the first 11 months of the covid-19 pandemic in Denmark. Although a gradual return close to baseline levels occurred for most major disease groups between lockdowns, hospital admission rates remained lower throughout the study period for some medical conditions; for example, respiratory and nervous system diseases, cancer, heart failure, acute exacerbations of chronic pulmonary disease, sepsis, and pneumonia. Concomitantly, higher 30 day mortality rates were observed overall and across a range of major disease groups during both national lockdowns and also between these time periods for respiratory diseases, cancer, pneumonia, and sepsis.

\section{Comparison with other studies}

Since the onset of the covid-19 pandemic, physicians and researchers around the world have been worried about the potential collateral effect on almost all

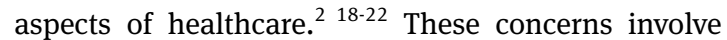
patients not seeking care when needed and reduced capacity of overburdened healthcare services to provide timely diagnoses and treatment. ${ }^{3-13}$ A recent report from four hospitals in New York, an epicentre of covid-19 at the early stages in the United States, reported decreases of more than $50 \%$ in overall hospital contacts across several major disease groups. ${ }^{5}$ These findings might partly reflect an overwhelmed healthcare system as suggested by another study that observed fewer hospital admissions at a tertiary care centre in New York compared with a similar facility in California, which was less severely affected by covid-19 at that time. ${ }^{4}$ In contrast, the overall decrease in hospital admission rates in the current study was a predictable consequence of the restrictions imposed by the Danish government at an early stage of the pandemic to ensure that hospitals could continue to provide 
essential healthcare. Although hospital admission rates gradually approached baseline levels for most major disease groups before the second national lockdown, important and substantially lower rates persisted for some serious medical conditions such as respiratory diseases and cancer. These lower rates were observed for new patients not being diagnosed and for patients with known disease not treated at hospital or monitored by specialised outpatient followup. Reports on the productivity of general practitioners by the Danish Board of Health observed that physical consultations also dropped markedly during the early stages of the covid-19 pandemic and were only partially replaced by telephone consultations, video calls, and

\begin{tabular}{|c|c|c|c|c|c|c|c|c|c|c|c|}
\hline \multirow[b]{2}{*}{ Cause } & \multirow{2}{*}{$\begin{array}{l}\text { Baseline } \\
\text { risk } \\
\text { (reference) }\end{array}$} & \multicolumn{2}{|c|}{ First national lockdown } & \multicolumn{2}{|c|}{ Gradual reopening } & \multicolumn{2}{|c|}{ Few restrictions } & \multicolumn{2}{|c|}{ Regional lockdowns } & \multicolumn{2}{|c|}{$\begin{array}{c}\text { Second national } \\
\text { lockdown }\end{array}$} \\
\hline & & Risk & $\begin{array}{l}\text { Risk ratio } \\
(95 \% \mathrm{Cl})\end{array}$ & Risk & $\begin{array}{l}\text { Risk ratio } \\
(95 \% \mathrm{Cl})\end{array}$ & Risk & $\begin{array}{l}\text { Risk ratio } \\
(95 \% \mathrm{Cl})\end{array}$ & Risk & $\begin{array}{l}\text { Risk ratio } \\
(95 \% \mathrm{Cl})\end{array}$ & Risk & $\begin{array}{l}\text { Risk ratio } \\
(95 \% \mathrm{Cl})\end{array}$ \\
\hline Overall & 5.3 & 6.9 & $\begin{array}{l}1.28 \\
(1.23 \text { to } 1.32)\end{array}$ & 5.6 & $\begin{array}{l}1.02 \\
(0.99 \text { to } 1.06)\end{array}$ & 5.3 & $\begin{array}{l}0.99 \\
(0.96 \text { to } 1.01)\end{array}$ & 5.6 & $\begin{array}{l}1.04 \\
\text { (1.01 to } 1.07)\end{array}$ & 6.6 & $\begin{array}{l}1.20 \\
\text { (1.16 to } 1.24)\end{array}$ \\
\hline $\begin{array}{l}\text { Including covid-19 } \\
\text { admissions }\end{array}$ & 5.3 & 7.4 & $\begin{array}{l}1.36 \\
(1.31 \text { to } 1.41) \\
\end{array}$ & 5.7 & $\begin{array}{l}1.04 \\
\text { (1.01 to } 1.08)\end{array}$ & 5.3 & $\begin{array}{l}0.99 \\
(0.97 \text { to } 1.01)\end{array}$ & 5.8 & $\begin{array}{l}.07 \\
\text { (1.04 to } 1.10)\end{array}$ & 7.4 & $\begin{array}{l}1.33 \\
(1.29 \text { to } 1.37) \\
\end{array}$ \\
\hline \multicolumn{12}{|l|}{ ICD-10 chapters } \\
\hline Infectious diseases & 9.8 & 13.5 & $\begin{array}{l}1.39 \\
\text { (1.23 to } 1.56)\end{array}$ & 9.7 & $\begin{array}{l}0.94 \\
(0.83 \text { to } 1.06)\end{array}$ & 9.3 & $\begin{array}{l}0.92 \\
(0.85 \text { to } 1.00)\end{array}$ & 11.9 & $\begin{array}{l}1.15 \\
(1.05 \text { to } 1.26) \\
\end{array}$ & 13.7 & $\begin{array}{l}1.32 \\
(1.18 \text { to } 1.48) \\
\end{array}$ \\
\hline $\begin{array}{l}\text { Including covid-19 } \\
\text { admissions }\end{array}$ & 9.7 & 15.7 & $\begin{array}{l}1.75 \\
\text { (1.60 to } 1.91)\end{array}$ & 11.0 & $\begin{array}{l}1.08 \\
(0.97 \text { to } 1.20)\end{array}$ & 9.4 & $\begin{array}{l}0.93 \\
\text { (0.86 to } 1.01)\end{array}$ & 12.4 & $\begin{array}{l}1.25 \\
(1.15 \text { to } 1.35) \\
\end{array}$ & 16.9 & $\begin{array}{l}1.72 \\
(1.60 \text { to } 1.85) \\
\end{array}$ \\
\hline Cancer & 9.6 & 10.5 & $\begin{array}{l}1.09 \\
\text { (0.99 to } 1.20)\end{array}$ & 10.5 & $\begin{array}{l}1.10 \\
(1.00 \text { to } 1.20)\end{array}$ & 10.2 & $\begin{array}{l}1.06 \\
\text { (0.99 to } 1.13)\end{array}$ & 10.7 & $\begin{array}{l}1.12 \\
\text { (1.04 to } 1.20)\end{array}$ & 10.9 & $\begin{array}{l}1.14 \\
\text { (1.04 to } 1.25)\end{array}$ \\
\hline Haematological disorders & 5.2 & 6.3 & $\begin{array}{l}1.15 \\
(0.89 \text { to } 1.49) \\
\end{array}$ & 5.2 & $\begin{array}{l}0.95 \\
(0.76 \text { to } 1.20)\end{array}$ & 4.9 & $\begin{array}{l}0.91 \\
(0.78 \text { to } 1.07)\end{array}$ & 5.4 & $\begin{array}{l}1.05 \\
(0.87 \text { to } 1.26) \\
\end{array}$ & 6.5 & $\begin{array}{l}1.19 \\
(0.95 \text { to } 1.49)\end{array}$ \\
\hline $\begin{array}{l}\text { Endocrine, nutrition, and } \\
\text { metabolism }\end{array}$ & 7.9 & 10.2 & $\begin{array}{l}1.17 \\
\text { (1.00 to } 1.37)\end{array}$ & 8.4 & $\begin{array}{l}1.02 \\
\text { (0.89 to } 1.17) \\
\end{array}$ & 8.0 & $\begin{array}{l}0.94 \\
(0.86 \text { to } 1.03)\end{array}$ & 8.0 & $\begin{array}{l}1.05 \\
(0.93 \text { to } 1.17)\end{array}$ & 8.8 & $\begin{array}{l}1.07 \\
\text { (0.92 to } 1.23)\end{array}$ \\
\hline $\begin{array}{l}\text { Mental and behavioural } \\
\text { disorders }\end{array}$ & 4.0 & 4.0 & $\begin{array}{l}0.95 \\
(0.62 \text { to } 1.45)\end{array}$ & 4.6 & $\begin{array}{l}1.08 \\
\text { (0.78 to } 1.48)\end{array}$ & 3.8 & $\begin{array}{l}0.95 \\
\text { (0.76 to } 1.18)\end{array}$ & 5.0 & $\begin{array}{l}1.19 \\
(0.92 \text { to } 1.53)\end{array}$ & 5.8 & $\begin{array}{l}1.42 \\
\text { (1.04 to } 1.95)\end{array}$ \\
\hline $\begin{array}{l}\text { Diseases of the nervous } \\
\text { system }\end{array}$ & 2.1 & 3.0 & $\begin{array}{l}1.31 \\
\text { (0.91 to } 1.88)\end{array}$ & 2.4 & $\begin{array}{l}1.07 \\
\text { (0.78 to } 1.47)\end{array}$ & 2.6 & $\begin{array}{l}1.23 \\
\text { (1.00 to } 1.52)\end{array}$ & 2.0 & $\begin{array}{l}0.98 \\
(0.74 \text { to } 1.29)\end{array}$ & 2.6 & $\begin{array}{l}1.18 \\
\text { (0.85 to } 1.65)\end{array}$ \\
\hline Sensory organ disease & 1.0 & 0.6 & $\begin{array}{l}0.58 \\
(0.14 \text { to } 2.40)\end{array}$ & 1.1 & $\begin{array}{l}1.05 \\
(0.45 \text { to } 2.44)\end{array}$ & 0.9 & $\begin{array}{l}0.83 \\
(0.45 \text { to } 1.53)\end{array}$ & 1.4 & $\begin{array}{l}1.35 \\
\text { (0.74 to } 2.48)\end{array}$ & 1.5 & $\begin{array}{l}1.40 \\
\text { (0.64 to } 3.06)\end{array}$ \\
\hline Circulatory disease & 5.6 & 6.9 & $\begin{array}{l}1.22 \\
\text { (1.11 to } 1.35)\end{array}$ & 5.7 & $\begin{array}{l}1.00 \\
(0.92 \text { to } 1.10)\end{array}$ & 5.6 & $\begin{array}{l}1.00 \\
(0.94 \text { to } 1.06)\end{array}$ & 6.0 & $\begin{array}{l}1.06 \\
(0.99 \text { to } 1.14) \\
\end{array}$ & 6.8 & $\begin{array}{l}1.18 \\
\text { (1.08 to } 1.29)\end{array}$ \\
\hline Respiratory diseases & 11.6 & 14.7 & $\begin{array}{l}1.26 \\
(1.17 \text { to } 1.36)\end{array}$ & 13.5 & $\begin{array}{l}1.16 \\
\text { (1.07 to } 1.25)\end{array}$ & 13.0 & $\begin{array}{l}1.12 \\
\text { (1.07 to } 1.18)\end{array}$ & 13.5 & $\begin{array}{l}1.17 \\
\text { (1.10 to } 1.24)\end{array}$ & 15.4 & $\begin{array}{l}1.28 \\
\text { (1.18 to } 1.38)\end{array}$ \\
\hline Digestive diseases & 4.3 & 5.6 & $\begin{array}{l}1.25 \\
\text { (1.10 to } 1.43)\end{array}$ & 4.0 & $\begin{array}{l}0.90 \\
\text { (0.79 to } 1.02)\end{array}$ & 4.3 & $\begin{array}{l}0.98 \\
(0.90 \text { to } 1.06)\end{array}$ & 4.4 & $\begin{array}{l}1.01 \\
(0.92 \text { to } 1.12)\end{array}$ & 5.5 & $\begin{array}{l}1.23 \\
\text { (1.09 to } 1.38)\end{array}$ \\
\hline Dermatological diseases & 2.2 & 4.1 & $\begin{array}{l}1.88 \\
\text { (1.13 to } 3.12)\end{array}$ & 2.3 & $\begin{array}{l}1.05 \\
(0.61 \text { to } 1.81)\end{array}$ & 2.0 & $\begin{array}{l}0.93 \\
(0.63 \text { to } 1.36)\end{array}$ & 1.9 & $\begin{array}{l}0.83 \\
(0.51 \text { to } 1.36) \\
\end{array}$ & 2.2 & $\begin{array}{l}0.96 \\
(0.52 \text { to } 1.77)\end{array}$ \\
\hline $\begin{array}{l}\text { Bone, muscle, and } \\
\text { connective tissues }\end{array}$ & 0.9 & 2.3 & $\begin{array}{l}2.32 \\
\text { (1.66 to } 3.23)\end{array}$ & 1.2 & $\begin{array}{l}1.25 \\
\text { (0.94 to } 1.66)\end{array}$ & 1.1 & $\begin{array}{l}1.11 \\
\text { (0.92 to } 1.35)\end{array}$ & 1.0 & $\begin{array}{l}1.05 \\
(0.83 \text { to } 1.32)\end{array}$ & 1.8 & $\begin{array}{l}1.84 \\
(1.39 \text { to } 2.44)\end{array}$ \\
\hline Genitourinary system & 4.7 & 6.1 & $\begin{array}{l}1.25 \\
(1.07 \text { to } 1.46)\end{array}$ & 5.6 & $\begin{array}{l}1.15 \\
(1.00 \text { to } 1.31)\end{array}$ & 4.7 & $\begin{array}{l}0.93 \\
(0.85 \text { to } 1.03)\end{array}$ & 5.2 & $\begin{array}{l}1.05 \\
(0.93 \text { to } 1.17)\end{array}$ & 6.2 & $\begin{array}{l}1.22 \\
(1.06 \text { to } 1.40)\end{array}$ \\
\hline Injury or poisoning & 4.0 & 5.2 & $\begin{array}{l}1.25 \\
\text { (1.10 to } 1.43) \\
\end{array}$ & 4.6 & $\begin{array}{l}1.12 \\
\text { (0.99 to } 1.26)\end{array}$ & 4.1 & $\begin{array}{l}1.01 \\
\text { (0.93 to } 1.10)\end{array}$ & 4.7 & $\begin{array}{l}1.12 \\
\text { (1.01 to } 1.24)\end{array}$ & 5.3 & $\begin{array}{l}1.21 \\
\text { (1.08 to } 1.36)\end{array}$ \\
\hline \multicolumn{12}{|c|}{ Selected acute medical conditions } \\
\hline Myocardial infarction & 4.7 & 4.8 & $\begin{array}{l}1.01 \\
(0.72 \text { to } 1.41)\end{array}$ & 4.4 & $\begin{array}{l}0.90 \\
(0.66 \text { to } 1.23)\end{array}$ & 4.7 & $\begin{array}{l}0.97 \\
(0.78 \text { to } 1.21)\end{array}$ & 4.4 & $\begin{array}{l}0.92 \\
(0.70 \text { to } 1.20)\end{array}$ & 5.5 & $\begin{array}{l}1.11 \\
\text { (0.84 to } 1.48)\end{array}$ \\
\hline Heart failure & 10.2 & 11.1 & $\begin{array}{l}1.10 \\
\text { (0.88 to } 1.39)\end{array}$ & 8.7 & $\begin{array}{l}0.83 \\
(0.67 \text { to } 1.03)\end{array}$ & 10.0 & $\begin{array}{l}0.99 \\
(0.86 \text { to } 1.15)\end{array}$ & 11.1 & $\begin{array}{l}1.06 \\
(0.90 \text { to } 1.26)\end{array}$ & 11.5 & $\begin{array}{l}1.11 \\
\text { (0.91 to } 1.36)\end{array}$ \\
\hline Stroke & 6.4 & 7.2 & $\begin{array}{l}1.12 \\
\text { (0.88 to } 1.42)\end{array}$ & 6.0 & $\begin{array}{l}0.92 \\
(0.73 \text { to } 1.15)\end{array}$ & 5.4 & $\begin{array}{l}0.84 \\
(0.72 \text { to } 0.99)\end{array}$ & 6.8 & $\begin{array}{l}1.04 \\
(0.87 \text { to } 1.25)\end{array}$ & 7.9 & $\begin{array}{l}1.20 \\
(0.97 \text { to } 1.47)\end{array}$ \\
\hline Intracranial bleeding & 22.1 & 24.3 & $\begin{array}{l}1.12 \\
\text { (0.86 to } 1.46)\end{array}$ & 23.2 & $\begin{array}{l}1.05 \\
\text { (0.82 to } 1.35)\end{array}$ & 25.0 & $\begin{array}{l}1.19 \\
\text { (1.01 to } 1.40)\end{array}$ & 25.3 & $\begin{array}{l}1.15 \\
(0.95 \text { to } 1.40)\end{array}$ & 26.3 & $\begin{array}{l}1.21 \\
\text { (0.96 to } 1.53)\end{array}$ \\
\hline $\begin{array}{l}\text { Acute exacerbation of } \\
\text { chronic pulmonary disease }\end{array}$ & 8.1 & 9.2 & $\begin{array}{l}1.14 \\
(0.96 \text { to } 1.36)\end{array}$ & 8.1 & $\begin{array}{l}0.98 \\
(0.82 \text { to } 1.17)\end{array}$ & 8.4 & $\begin{array}{l}1.04 \\
\text { (0.93 to } 1.16)\end{array}$ & 9.4 & $\begin{array}{l}1.15 \\
\text { (1.00 to } 1.32)\end{array}$ & 11.3 & $\begin{array}{l}1.33 \\
\text { (1.13 to } 1.56)\end{array}$ \\
\hline Pneumonia & 13.3 & 18.4 & $\begin{array}{l}1.40 \\
\text { (1.27 to } 1.55)\end{array}$ & 17.1 & $\begin{array}{l}1.30 \\
(1.17 \text { to } 1.44)\end{array}$ & 16.2 & $\begin{array}{l}1.20 \\
(1.12 \text { to } 1.28)\end{array}$ & 17.2 & $\begin{array}{l}1.30 \\
\text { (1.19 to } 1.41)\end{array}$ & 19.0 & $\begin{array}{l}1.38 \\
(1.25 \text { to } 1.53)\end{array}$ \\
\hline Sepsis & 15.0 & 19.8 & $\begin{array}{l}1.39 \\
(1.23 \text { to } 1.57)\end{array}$ & 14.0 & $\begin{array}{l}0.91 \\
(0.81 \text { to } 1.03)\end{array}$ & 15.3 & $\begin{array}{l}1.00 \\
(0.92 \text { to } 1.08)\end{array}$ & 17.5 & $\begin{array}{l}1.15 \\
\text { (1.04 to } 1.26)\end{array}$ & 18.3 & $\begin{array}{l}1.20 \\
\text { (1.07 to } 1.35)\end{array}$ \\
\hline Urinary tract infection & 6.5 & 8.0 & $\begin{array}{l}1.23 \\
\text { (1.01 to } 1.50)\end{array}$ & 7.0 & $\begin{array}{l}1.06 \\
(0.89 \text { to } 1.26)\end{array}$ & 6.5 & $\begin{array}{l}0.97 \\
\text { (0.86 to } 1.09 \text { ) }\end{array}$ & 7.5 & $\begin{array}{l}1.09 \\
(0.94 \text { to } 1.25)\end{array}$ & 7.1 & $\begin{array}{l}1.04 \\
\text { (0.87 to } 1.25) \\
\end{array}$ \\
\hline $\begin{array}{l}\text { Bone, skin, and soft } \\
\text { tissue infections }\end{array}$ & 3.4 & 3.6 & $\begin{array}{l}1.09 \\
\text { (0.69 to } 1.72)\end{array}$ & 3.8 & $\begin{array}{l}1.03 \\
(0.72 \text { to } 1.49)\end{array}$ & 2.4 & $\begin{array}{l}0.67 \\
(0.50 \text { to } 0.89)\end{array}$ & 4.2 & $\begin{array}{l}1.16 \\
(0.86 \text { to } 1.56)\end{array}$ & 4.8 & $\begin{array}{l}1.32 \\
\text { (0.93 to } 1.88)\end{array}$ \\
\hline
\end{tabular}

ICD-10=international classification of diseases version 10 .

Mortality rate ratio adjusted for age and sex. Patients admitted to hospital with non-covid-19 medical conditions and subsequently with a diagnosis of covid-19 within 30 days of the index date were censored at day of covid-19 diagnosis. 
e-mail. ${ }^{23} 24$ This decrease was especially pronounced for children aged 0-4 years, adults aged $>70$ years, and immigrants. By late April 2020, consultations had returned to baseline levels, suggesting no major shift in management of serious diseases from hospital to primary care.

A few previous reports also observed lower hospital admission rates for myocardial infarctions, ${ }^{6}$ 10-12 heart failure, ${ }^{59}$ and stroke ${ }^{3813}$ during the initial peak of covid-19 that were comparable to or even more pronounced than estimates of the current study. In general, fewer hospital admissions could represent genuinely lower incidences of diseases because of lifestyle and behavioural changes during lockdown. However, concerns remain about reluctance of patients to seek care because of perceived risks of contracting covid-19 at hospital, negligence to report symptoms, and decreased hospital capacity to manage these patients. In our study, the moderately lower hospital admission rates for acute myocardial infarction and stroke during lockdown were mainly driven by fewer patients with a first time diagnosis, whereas the persistently lower rates observed in patients with heart failure might partly represent deferred outpatient follow-up. Physical distancing and hygienic precautions probably contributed to fewer admissions for respiratory tract infections and sepsis, whereas reasons for the observed decreases in urinary tract infections or bone, skin, and soft tissue infections are less obvious.

\section{Clinical implications}

A potential and concerning consequence of patients not seeking appropriate care for medical emergencies could be an increase in mortality and morbidity. In contrast to some other countries, we did not observe an overall excess mortality on a population level in Denmark until the second national lockdown in December 2020 (fig 1). ${ }^{25-29}$ A key component of this observation is probably the greater severity of the second wave of covid-19 in Denmark and associated deaths, which might have outweighed the decreased overall absolute number of hospital admissions and deaths due to other conditions at that time. The findings of higher relative mortality rates for patients admitted with other infections that could mimic covid-19, such as pneumonia, sepsis, and urinary tract infections, were also of great concern. These higher rates could be due to delayed presentation and progression to more severe disease in some patients. Additionally, the implementation of isolation precautions in a burdened healthcare system (primary and hospital care) could further hinder appropriate examinations and time dependent treatments.

These results should be interpreted with caution and additional studies are needed to clarify whether our observations represent a significantly higher mortality rate adjusted for disease severity, or whether they merely reflect increased self or primary care management of less severe conditions. Because cancer is an adverse prognostic factor of covid-19, ${ }^{30}{ }^{31}$ the higher mortality rate in these patients could be attributable to undiagnosed covid-19. Other reasons might include the accumulation of more insidious adverse collateral effects of the pandemic on timely diagnosis and long term management of patients with cancer.

\section{Limitations and generalisability}

Important limitations include lack of access to data on primary care management for estimates on disease frequencies, and clinical details on disease severity and comorbidities of people admitted to hospital in analyses of mortality. Danish healthcare and administrative registries have been shown to be of high quality, ${ }^{14} 1632$ but differential misclassification of conditions with a similar clinical presentation as covid-19 cannot be excluded and could introduce bias in an unpredictable direction. Although our results might not be directly comparable to some healthcare systems, the generalisability is strengthened by the nationwide and population based setting within a tax financed healthcare system accounting for all hospital admissions and the vital status of each Danish resident on the individual level.

\section{Conclusions}

Hospital admission rates were substantially lower for all major non-infectious disease groups during the two national lockdowns. Although hospital admissions had gradually returned to baseline levels for many conditions in the time periods between lockdowns, important exceptions were respiratory and nervous system diseases, cancer, pneumonia, sepsis, and heart failure. At the same time, higher 30 day mortality rates were observed for most major disease groups during national lockdowns, but also in the time periods between the lockdowns for hospital admissions due to respiratory diseases, cancer, pneumonia, and sepsis.

Contributors: JB, TY, LOZS, FS, PBN, MS, MDP, HN, and TBL conceived and designed the study. FS performed the data management and conducted all statistical analyses. JB wrote the first draft and is the guarantor for the study. The corresponding author attests that all listed authors meet authorship criteria and that no others meeting the criteria have been omitted.

Funding: None.

Competing interests: All authors have completed the ICMJE uniform disclosure form at www.icmje.org/coi_disclosure.pdf and declare: no support from any organisation for the submitted work; no financial relationships with any organisations that might have an interest in the submitted work in the previous three years; no other relationships or activities that could appear to have influenced the submitted work.

Ethical approval: The study was approved by the legal representatives of North Denmark Region (2020-046). In Denmark, patient consent or approval from an ethics committee is not necessary for this type of study. The data were provided by the Danish Health Data Authority.

Data sharing: For legal reasons, individual level raw data from Danish administrative and health registries cannot be shared by the authors. The lead author (JB) affirms that this manuscript is an honest, accurate, and transparent account of the study being reported; that no important aspects of the study have been omitted; and that any discrepancies from the study as planned (and, if relevant, registered) have been explained.

Dissemination to participants and related patient and public communities: Besides publication in the British Medical Journal, the main results of the study will be announced in a press release by the North Denmark Region. 
Provenance and peer review: Not commissioned; externally peer reviewed.

This is an Open Access article distributed in accordance with the Creative Commons Attribution Non Commercial (CC BY-NC 4.0) license, which permits others to distribute, remix, adapt, build upon this work non-commercially, and license their derivative works on different terms, provided the original work is properly cited and the use is noncommercial. See: http://creativecommons.org/licenses/by-nc/4.0/.

1 World Health Organization. WHO releases guidelines to help countries maintain essential health services during the COVID-19 pandemic. 2020. https://www.who.int/news-room/detail/30-032020-who-releases-guidelines-to-help-countries-maintain-essentialhealth-services-during-the-covid-19-pandemic.

2 Rosenbaum $L$. The untold toll - the pandemic's effects on patients without Covid-19. New Engl / Med . 2020. doi:10.1056/ nejmms2009984

3 Baum A, Schwartz MD. Admissions to Veterans Affairs hospitals for emergency conditions during the COVID-19 pandemic. IAMA 2020;324:96-9. doi:10.1001/jama.2020.9972

4 Bhambhvani HP, Rodrigues AJ, Yu JS, Carr JB2nd, Hayden Gephart M. Hospital volumes of 5 medical emergencies in the COVID-19 pandemic in 2 US medical centers. JAMA Intern Med 2021;181:272 4. doi:10.1001/jamainternmed.2020.3982

5 Blecker S, Jones SA, Petrilli CM, et al. Hospitalizations for chronic disease and acute conditions in the time of COVID-19. JAMA Intern Med 2021;181:269-71. doi:10.1001/jamainternmed.2020.3978

6 De Rosa S, Spaccarotella C, Basso C, et al, Società Italiana di Cardiologia and the CCU Academy investigators group. Reduction of hospitalizations for myocardial infarction in Italy in the COVID-19 era. Eur Heart J 2020;41:2083-8. doi:10.1093/eurheartj/ehaa409

7 Baldi E, Sechi GM, Mare C, et al. Out-of-hospital cardiac arrest during the covid-19 outbreak in Italy. New Engl I Med . 2020. doi:10.1056/ nejmc2010418

8 Rinkel LA, Prick JCM, Slot RER, et al. Impact of the COVID-19 outbreak on acute stroke care. J Neurol . 2020. doi:10.1007/s00415-02010069-1

9 Sokolski M, Gajewski P, Zymlinski R, et al. Impact of coronavirus disease 2019 (COVID-19) outbreak on acute admissions at the emergency and cardiology departments across Europe. Am J Med. 2020. doi:10.1016/j.amjmed.2020.08.043

10 Garcia S, Albaghdadi MS, Meraj PM, et al. Reduction in ST-segment elevation cardiac catheterization laboratory activations in the United States during COVID-19 pandemic. J Am Coll Cardiol . 2020. doi:10.1016/j.jacc.2020.04.011

11 Solomon MD, McNulty EJ, Rana JS, et al. The covid-19 pandemic and the incidence of acute myocardial infarction. New Engl J Med . 2020. doi:10.1056/nejmc2015630

12 Filippo OD, D'Ascenzo F Angelini F et al. Reduced rate of hospital admissions for ACS during covid-19 outbreak in northern Italy. New Engl J Med . 2020. doi:10.1056/nejmc2009166

13 Kansagra AP, Goyal MS, Hamilton S, Albers GW. Collateral effect of Covid-19 on stroke evaluation in the United States. N Engl Med 2020;383:400-1. doi:10.1056/NEJMc2014816

14 Schmidt M, Schmidt SAJ, Adelborg K, et al. The Danish health care system and epidemiological research: from health care contacts to database records. Clin Epidemiol 2019;11:563-91. doi:10.2147/ CLEP.S179083

15 Schmidt M, Pedersen L, Sørensen HT. The Danish Civil Registration System as a tool in epidemiology. Eur J Epidemiol 2014;29:541-9. doi:10.1007/s10654-014-9930-3

16 Schmidt M, Schmidt SAJ, Sandegaard JL, Ehrenstein V, Pedersen L, Sørensen HT. The Danish National Patient Registry: a review of content, data quality, and research potential. Clin Epidemiol 2015;7:449-90. doi:10.2147/CLEP.S91125

17 Danish Board of Health. Covid-19 status and management in Denmark. 2021. https://www.sst.dk/da/corona/Status-forepidemien/Statusrapporter

18 Nelson B. Covid-19 is shattering US cancer care. BMJ 2020;369:m1544. doi:10.1136/bmj.m1544

19 Dore B. Covid-19: collateral damage of lockdown in India. BMJ 2020;369:m1711. doi:10.1136/bmj.m1711

20 Mayor S. COVID-19: impact on cancer workforce and delivery of care. Lancet Oncol 2020;21:633. doi:10.1016/S1470-2045(20)30240-

21 Dejong C, Katz MH, Covinsky K. Deferral of care for serious nonCOVID-19 conditions: a hidden harm of COVID-19. JAMA Intern Med 2021;181:274. doi:10.1001/jamainternmed.2020.4016

22 Anil I, Arnold R, Benkwitz-Beford S, et al. The UK Coronavirus Cancer Monitoring Project: protecting patients with cancer in the era of COVID-19. Lancet Oncol . 2020. doi:10.1016/S14702045(20)30230-8

23 The Danish Board of Health (Danish). COVID-19: Monitorering af aktivitet i sundhedsvæsenet. Beskrivelse af udviklingen i aktivitet i sundhedsvæsenet under COVID-19 epidemien -6. rapport. 2021. https://www.sst.dk//media/Udgivelser/2020/Corona/Monitorering/ MonitoreringsrapportAktivitet_6_rapport180221.ashx?la=da\&hash= B71A6E7915665D8F6B5E2BA6EBADE7B162900367.

24 The Danish Board of Health (Danish). General practice in Denmark - monitoring and analyses. 2021. https://sundhedsdatastyrelsen. $\mathrm{dk} / \mathrm{da} /$ tal-og-analyser/analyser-og-rapporter/sundhedsvaesenet/ almenpraksis.

25 Kontis V, Bennett JE, Rashid T, et al. Magnitude, demographics and dynamics of the effect of the first wave of the COVID-19 pandemic on all-cause mortality in 21 industrialized countries. Nat Med 2020:26:1919-28, doi:10.1038/s41591-020-1112-0

26 Lai AG, Pasea L, Banerjee A, et al. Estimated impact of the COVID-19 pandemic on cancer services and excess 1 -year mortality in people with cancer and multimorbidity: near real-time data on cancer care, cancer deaths and a population-based cohort study. BM Open 2020;10:e043828. doi:10.1136/bmjopen-2020-043828

27 Bilinski A, Emanuel El. COVID-19 and excess all-cause mortality in the US and 18 comparison countries. JAMA 2020;324:2100-2. doi:10.1001/jama.2020.20717

28 Vestergaard LS, Nielsen J, Richter L, et al, ECDC Public Health Emergency Team for COVID-19. Excess all-cause mortality during the COVID-19 pandemic in Europe - preliminary pooled estimates from the EuroMOMO network, March to April 2020. Euro Surveill 2020;25:2001214. doi:10.2807/1560-7917. ES.2020.25.26.2001214

29 Weinberger DM, Chen J, Cohen T, et al. Estimation of excess deaths associated with the COVID-19 pandemic in the United States, March to May 2020. JAMA Intern Med 2020;180:1336-44. doi:10.1001/ jamainternmed.2020.3391

30 Lee LYW, Cazier JB, Starkey T, et al. COVID-19 mortality in patients with cancer on chemotherapy or other anticancer treatments: a prospective cohort study. The Lancet . 2020. doi:10.1016/S01406736(20)31173-9

31 Reilev M, Kristensen KB, Pottegård A, et al. Characteristics and predictors of hospitalization and death in the first 11122 cases with a positive RT-PCR test for SARS-CoV-2 in Denmark: a nationwide cohort. Int J Epidemiol 2020;49:1468-81. doi:10.1093/ije/dyaa140

32 Frank L. Epidemiology. When an entire country is a cohort. Science 2000;287:2398-9. doi:10.1126/science.287.5462.2398

Web appendix: Supplementary material 